\title{
Aqueous Biphase Extraction for Processing of Fine Coal
}

Grant No. DE-FG22-96 PC96211

Semi-Annual Report

Reporting Period Start Date: 04/01/99

Reporting Period End Date: 10/01/99

Principal Author: K. Osseo-Asare, Professor of Metallurgy

Date Report was issued: 12/21/1999

DOE Award Number: DE-FG22-96 PC96211

Submitting organization: Metals Science and Engineering Program Department of Materials Science and Engineering 209 Steidle Building Penn State University University Park, PA 16802 


\section{DISCLAIMER}

This report was prepared as an account of work sponsored by an agency of the United States Government. Neither the United States Government nor any agency thereof, nor any of their employees, makes any warranty, express or implied, or assumes any legal liability or responsibility for the accuracy, completeness, or usefulness of any information, apparatus, product, or process disclosed, or represents that its use would not infringe privately owned rights. Reference herein to any specific commercial product, process, or service by trade name, manufacturer, or otherwise does not necessarily constitute or imply its endorsement, recommendation, or favoring by the United States Government or any agency thereof. The views and opinions of authors expressed herein do not necessarily state or reflect those of the United States Government or any agency thereof. 


\section{DISCLAIMER}

Portions of this document may be illegible in electronic image products. Images are produced from the best available original document. 


\begin{abstract}
Ever-stringent environmental constraints dictate that future coal cleaning technologies be compatible with micron-size particles. This research program seeks to develop an advanced coal cleaning technology uniquely suited to micron-size particles, i.e., aqueous biphase extraction. The partitioning behavior of fly ash in the PEG$2000 / \mathrm{Na}_{2} \mathrm{SO}_{4} / \mathrm{H}_{2} \mathrm{O}$ system was studied and the effects of $\mathrm{pH}$ and $\mathrm{H}_{2} \mathrm{O}_{2}$ were also investigated. In the $\mathrm{pH}$ range of 4 to 9 , the particles separated into two different layers, i.e., the polymer-rich and salt-rich phases. However, above $\mathrm{pH} 10$, the particles in the polymer-rich phase divided into two zones. The percent carbon content of the solids in the upper zone was higher than that in the original sample, while the lower zone in the polymer-rich phase had the same percent ash content as the original sample. The particles in the salt-rich phase were mainly composed of ash. The composition of the ash in each region remained almost the same. Addition of $\mathrm{H}_{2} \mathrm{O}_{2}$ increased the phase separation rate; however, it had no effect on the ash content and ash composition.
\end{abstract}




\section{TABLE OF CONTENTS}

Abstract....................................................................... 3

List of Figures.......................................................... 5

List of Tables.............................................................. 6

Executive Summary....................................................... 7

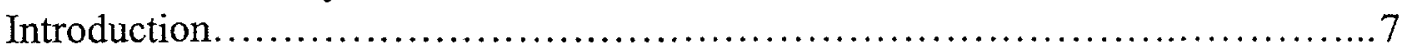

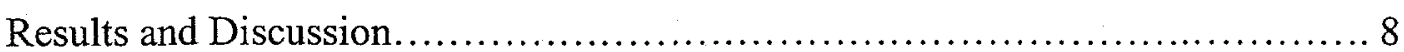

Conclusions.............................................................. 10

References.............................................................. 10

Publications Published/Submitted........................................... 11 


\section{LIST OF FIGURES}

Fig. 1 Effect of $\mathrm{pH}$ on the partition of fly ash in the PEG-2000/ $\mathrm{Na}_{2} \mathrm{SO}_{4} / \mathrm{H}_{2} \mathrm{O}$ system 12

Fig. 2 The ash contents in each region with or without $\mathrm{H}_{2} \mathrm{O}_{2}$ at $\mathrm{pH} 12 \ldots \ldots \ldots \ldots . .13$ 


\section{LIST OF TABLES}

Table 1 Composition of ash in each region with or without $\mathrm{H}_{2} \mathrm{O}_{2}$ at $\mathrm{pH} 12$ 


\section{EXECUTIVE SUMMARY}

The objective of this research project is to develop an aqueous biphase extraction process for the treatment of fine coals. Aqueous biphase extraction is an advanced separation technology and it relies on the ability of an aqueous system consisting of a water-soluble organic polymer and an inorganic salt to separate into two immiscible aqueous phases. Differences in the hydrophobic/hydrophilic properties of particulates can then be exploited to effect selective transfers to either the top polymer-rich phase, or the bottom salt-rich phase. The goal of this experimental program is to identify process conditions that optimize the selective transfer of coal into the top phase while retaining the mineral matter in the bottom phase. An additional goal is to develop an improved coal-pyrite separation technique based on aqueous biphase extraction.

The partitioning behavior of fly ash in the PEG-2000/ $/ \mathrm{Na}_{2} \mathrm{SO}_{4} / \mathrm{H}_{2} \mathrm{O}$ system was studied and the effects of $\mathrm{pH}$ and $\mathrm{H}_{2} \mathrm{O}_{2}$ were also investigated. In the $\mathrm{pH}$ range of 4 to 9 , the particles separated into two different layers, i.e., the polymer-rich and salt-rich phases. However, above $\mathrm{pH} 10$, the particles in the polymer-rich phase divided into two zones. The percent carbon content of the solids in the upper zone was higher than that in the original sample, while the lower zone in the polymer-rich phase had the same percent ash content as the original sample. The particles in the salt-rich phase were mainly composed of ash. The composition of the ash in each region remained almost the same. Addition of $\mathrm{H}_{2} \mathrm{O}_{2}$ increased the phase separation rate; however, it had no effect on the ash content and ash composition.

\section{INTRODUCTION}

Coal represents the largest source of fossil energy in the U.S. This resource also represents the most readily accessible and socially acceptable substitute for oil and natural gas. In response to the stipulations of the Clean Air Act (1), advanced coal cleaning technologies are needed in order to more efficiently eliminate unacceptable levels of ash and sulfur from the run-of-mine coal prior to combustion. The ability to achieve mineral matter liberation from coal is fundamental to all separation techniques that seek to produce super-clean coal. It has been concluded from the microscopic examination of a wide variety of U.S. coals that, in many cases, grinding to $10 \mu \mathrm{m}$ or below may be necessary in order to achieve the necessary liberation (2). It is clear, therefore, that future advanced coal cleaning technologies must be capable of accommodating micron size particles.

This project seeks to investigate the feasibility of separating pyrite and mineral materials from fine coal by using aqueous biphase extraction. Although aqueous biphase systems have been known for more than 100 years, it was only in the mid 50s that their potential use as separation media was recognized. Albertsson who pioneered the separation of microbial cells, cell organelles, and virus (3) performed the initial work. In recent years, interest in aqueous biphase extraction has broadened to applications in the commercial-scale separation of proteins (5), as well as separation of metal ions (6), 
ultrafine particles (7), and organics (8). Chaiko et al. used aqueous biphase extraction to remove radioactive residue from soil $(4,9)$. Compared with conventional organicsolvent-based liquid-liquid extraction, aqueous biphase extraction is especially attractive for waste treatment applications, because it avoids the use of an organic solvent which itself is a possible pollutant. In addition, the polymers used in aqueous biphase systems are generally inexpensive, nontoxic, and biodegradable (7).

It is possible to form a two-phase system in certain polymer/inorganic salt/water mixtures. When the concentrations of the salt and polymer exceed certain limits, the aqueous system separates into two immiscible phases, in which the top phase is polymerrich and the bottom phase is enriched in salt. Aqueous biphase extraction is very similar to conventional solvent extraction. Just like the organic solvent/water two-phase systems, the top phase of the aqueous biphase system is more hydrophobic, and the bottom phase is more hydrophilic. The hydrophobic/hydrophilic character of the particle surface determines the partitioning of the particles into either the top more hydrophobic phase or the bottom more hydrophilic phase. Thus, differences in the surface chemistry of particles can be exploited for selective separations.

Fly ash, as a major coal combustion byproduct (CCB), is produced in the amount of 50 million tons/year in the USA (10). The utilization of fly ash is about $20 \%$, most of this is used in the cement industry, as a road base, and as structural fills (11). In response to the Clean Air Act Amendment of 1990, low temperature combustion of coal is being carried out in order to reduce the emission levels of $\mathrm{NO}_{\mathrm{x}}$ and $\mathrm{SO}_{\mathbf{x}}$. However, as a side effect of this new technology, the carbon content in fly ash is increased significantly. This limits the utility of fly ash as a constructing material in the cement industry $(12,13)$. High amounts of carbon in fly ash that is used in concrete promote the undesirable adsorption of air-entraining admixtures in concrete (these admixtures are added in order to prevent cracking). It is necessary to separate the high carbon component from ash in fly ash. Also, beneficiated fly ash has potential applications as a raw material for the synthesis of mullite $(10,14)$, as fillers in the plastic industry $(15)$, and as adsorbents $(12,16)$. This report focuses on the partitioning behavior of fly ash in polyethylene glycol (PEG)/salt/water aqueous biphase systems. The effects of $\mathrm{pH}$ and $\mathrm{H}_{2} \mathrm{O}_{2}$ were investigated.

\section{RESULTS AND DISCUSSION \\ Particle Characterization and Effect of Particle Size on Partition of Fly Ash}

Fly ash was obtained from the Coal Utilization Laboratory, Penn State University. It was screened with ASTM certified screens, and the -400 mesh fraction was collected. The specific surface area was $7.1 \mathrm{~m}^{2} / \mathrm{g}$, which was determined by BET. Particle size analysis for the -400 mesh fraction of fly ash was carried out with a Microtrac-X100. The $\mathrm{X}_{20}, \mathrm{X}_{50}, \mathrm{X}_{80}$ sizes were $8.12,17.63,27.65 \mu \mathrm{m}$, respectively. The sample consisted of 74 wt $\%$ carbon and $26 \mathrm{wt} \%$ ash. $\mathrm{SiO}_{2}$ and $\mathrm{Al}_{2} \mathrm{O}_{3}$ were the main components of the ash. At $\mathrm{pH} 8$, all the fly ash particles stayed at the interface when the original unscreened sample 
( +400 mesh and -400 mesh) was used. However, when the -400 mesh sample was tested, separation of the solids between the two aqueous phases took place.

\section{Effect of pH on Partition of Fly Ash}

Figure 1 shows the effect of $\mathrm{pH}$ on the partition of fly ash in the PEG$2000 / \mathrm{Na}_{2} \mathrm{SO}_{4} / \mathrm{H}_{2} \mathrm{O}$ system. In the $\mathrm{pH}$ range of 4 to 9 , two kinds of solid fractions were obtained. The particles in the salt-rich phase were brown, and the color of the particles in the polymer-rich phase was black. However, above $\mathrm{pH} 10$, the particles in the polymerrich phase divided into two zones. The upper zone was still black, while the newly formed lower zone was grayish. At $\mathrm{pH} \mathrm{12,} \mathrm{most} \mathrm{of} \mathrm{the} \mathrm{fly} \mathrm{ash} \mathrm{was} \mathrm{concentrated} \mathrm{in} \mathrm{the}$ lower zone of the polymer-rich phase.

Figure 2 shows the ash content in each region at $\mathrm{pH} \mathrm{12,} \mathrm{with} \mathrm{or} \mathrm{without} \mathrm{H}_{2} \mathrm{O}_{2}$. The particles in the salt-rich phase were mainly ash. The percent ash content in the upper zone in the polymer-rich phase decreased from $26 \mathrm{wt} \%$ (in the original sample) to $15 \mathrm{wt} \%$, while the particles in the lower zone of the salt-rich phase had the same proportion of carbon and ash as the original sample. Table 1 lists the composition of the ash component in each region. It can be seen that the composition of the ash was nearly the same in each region.

From the above results, it appears that materials with higher carbon content than the original sample concentrated in the upper zone of polymer-rich phase at $\mathrm{pH} 12$. It is speculated that the surface of the solids in the upper zone was mainly composed of carbon, and it was highly hydrophobic. Accordingly these particles went into the polymer-rich phase. The particles in the lower zone of the salt-rich phase had the same ash content as the original sample. The particles in this region had both carbon and oxide on the surface, which made them both hydrophilic and hydrophobic. In principle, these particles should stay at the interface. However, the area of the interface was so small that it was impossible to accommodate all the particles. Probably, the surface was slightly more hydrophobic, so the particles went into the polymer-rich phase and formed the lower zone. Because the solids in the salt-rich phase had a high content of ash, the surface of these particles is expected to be hydrophilic. Therefore, it is easy to understand their partition into the salt-rich phase.

\section{Effect of $\mathrm{H}_{2} \mathrm{O}_{2}$,on Partition of Fly Ash}

Without any additive, phase separation was completed in about 15 minutes for the system containing $1 \mathrm{wt} \%$ solids. In the presence of $\mathrm{H}_{2} \mathrm{O}_{2}$, phase separation was completed in about 5 minutes. However, addition of $\mathrm{H}_{2} \mathrm{O}_{2}$ had no effect on the solid composition (as shown in Table 1 and Figure 2) and the yield in each region. It seems that hydrogen peroxide only accelerated the phase separation. The exact mechanism of this phenomenon is not clear. 


\section{CONCLUSIONS}

In order to improve the utility of fly ash, it is necessary separate the high carbon fraction from the ash. This report studied the partitioning behavior of fly ash in the PEG$2000 / \mathrm{Na}_{2} \mathrm{SO}_{4} / \mathrm{H}_{2} \mathrm{O}$ system, including the effects of $\mathrm{pH}$ and $\mathrm{H}_{2} \mathrm{O}_{2}$. In the $\mathrm{pH}$ range of 4 to 9 , the particles partitioned into two aqueous phases. Above $\mathrm{pH} 10$, the particles in the polymer-rich phase divided into two zones. The percent carbon content in the upper zone was higher than that in the original sample, and the lower zone had the same percent ash content as the original sample. The particle in the salt-rich phase was mainly ash. The composition of the ash in each region remained almost the same. Addition of $\mathrm{H}_{2} \mathrm{O}_{2}$ accelerated the phase separation; however, it had no effect on the ash content and ash composition.

\section{REFERENCES}

1. Asst. Sec. of State for Fossil Energy, Clean Coal Technology: The New Coal Era, U. S. Department of Energy, June, 1990

2. M. J. Mankosa, G. F. Adel, and R. H. Yoon, Powder Tech., 1986, 49: 75

3. P. A. Albertsson, Partition of Cell Particles and Macromolecules, 3rd. Ed., WileyInterscience: New York, 1986

4. D. J. Chaiko, R. Mensah-Biney, C. J. Mertz, and A. Rollins, Sep. Sci. Technol., 1993, 28: 765

5. H. Walter, D. E. Brooks, and D. Fisher Eds., Partitioning in Aqueous Two-Phase Systems, Academic Press: New York, 1985

6. R. D. Rogers, A. H. Bord, and C. B. Bauer, Sep. Sci. Technol., 1993, 28: 1091

7. K. P. Ananthapadmanabhan and E. D. Goddard, Process for the Separation of Solid Particulate Matters, U. S. Patent 47,225,358, 1987

8. D. J. Chaiko et al., in Proceeding $14^{\text {th }}$ Annual Army Environmental R\&D Symposium, 1989, p. 305

9. D. J. Chaiko, Y. Vojta, and M. Takeuchi, Sep. Sci. Technol., 1995, 30: 1123

10. X. Huang, J. Y. Hwang, and B. C. Mutsuddy, Interceram, 1995, 44:65

11. S. Tyson and T. Blackstock, Preprint of ACS Div. Of Fuel Chem., 1998, $41: 587$

12. I. Kulaots, Y.-M. Gao, R. H. Hurt, and E. M. Suuberg, Preprint of ACS Div. Of Fuel Chem., 1998, 41:980

13. X. M. Song' J.-Y. Hwang, and X.-P. Liu, Proc. $12^{\text {th }}$ Intern. Symp. on Coal Combustion By-Product (CCB) Management and Use, 1997, V1:30-1

14. J.-Y. Hwang, X. Huang, and A. Hein, JOM, 1994, May:36

15. X. Huang, J.-Y. Hwang, and J. M. Gillis, Proc. $12^{\text {th }}$ Intern. Symp. on Coal Combustion By-Product (CCB) Management and Use, 1997, V1:22-1

16. U. M. Graham, J. G. Groppo, and T. L. Robl, Preprint of ACS Div. Of Fuel Chem., 1998, 41:985 


\section{PUBLICATIONS PUBLISHED/SUBMITTED}

1. K. Osseo-Asare and X. Zeng, Aqueous Biphasic Extraction of Particulates: Controlling the Hydrophilic-Hydrophobic Balance for Separation, in: K. C. Liddell and D. J. Chaiko (Eds.), Metal Separation Technologies Beyond 2000, The Minerals, Metals, and Materials Soc., Warrendale, PA, 1999, p. 347

2. K. Osseo-Asare and X. Zeng, Partition of Pyrite in Aqueous Biphase Systems, Intern. J. Miner. Proc., in press 
Figure 1. Effect of $\mathrm{pH}$ on the partition of fly ash in the PEG-2000/ $\mathrm{Na}_{2} \mathrm{SO}_{4} / \mathrm{H}_{2} \mathrm{O}$ system.

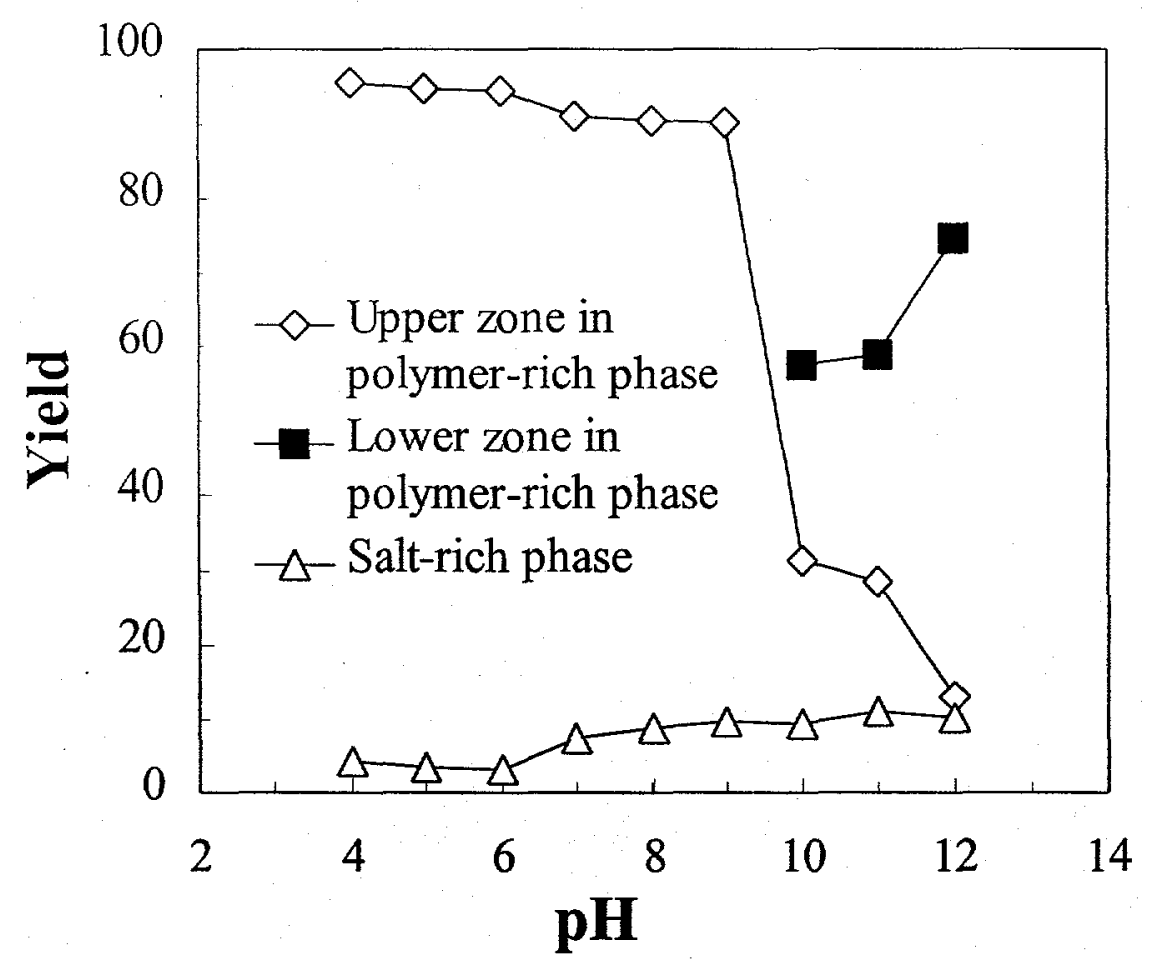


Figure 2. The ash content in each region with or without $\mathrm{H}_{2} \mathrm{O}_{2}$ at $\mathrm{pH} 12$.

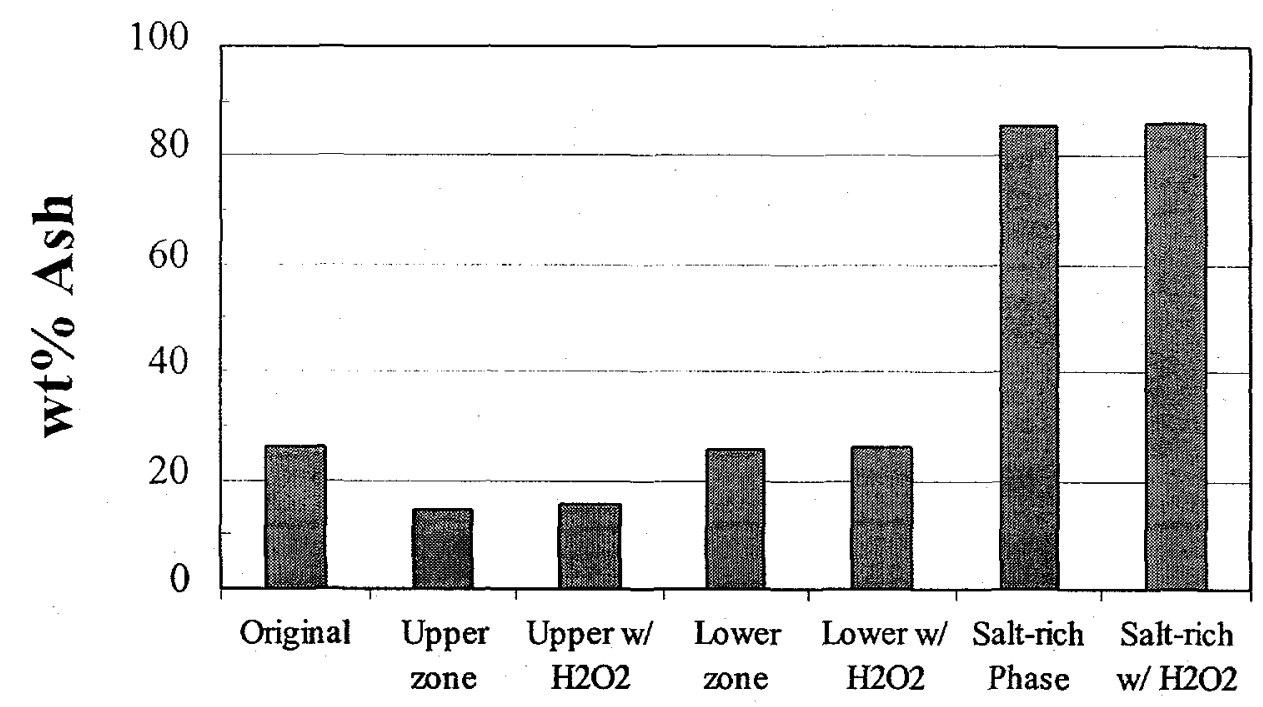


Table 1. Composition of ash in each region with or without $\mathrm{H}_{2} \mathrm{O}_{2}$ at $\mathrm{pH} 12$.

\begin{tabular}{|c|c|c|c|c|c|c|}
\hline Name & $\begin{array}{c}\text { Upper zone } \\
\text { in polymer- } \\
\text { rich phase }\end{array}$ & $\begin{array}{c}\text { Upper zone } \\
w / \mathrm{H}_{2} \mathrm{O}_{2}\end{array}$ & $\begin{array}{c}\text { Lower zone } \\
\text { in polymer- } \\
\text { rich phase }\end{array}$ & $\begin{array}{c}\text { Lower zone } \\
w / \mathrm{H}_{2} \mathrm{O}_{2}\end{array}$ & $\begin{array}{c}\text { Salt-rich } \\
\text { phase }\end{array}$ & $\begin{array}{c}\text { Salt-rich } \\
\text { phase w/ } \\
\mathrm{H}_{2} \mathrm{O}_{2}\end{array}$ \\
\hline $\mathrm{SiO}_{2}$ & 48.7 & 46.0 & 50.0 & 50.2 & 55.2 & 53.9 \\
\hline $\mathrm{Al}_{2} \mathrm{O}_{3}$ & 31.0 & 30.3 & 32.0 & 31.8 & 31.9 & 31.5 \\
\hline $\mathrm{TiO}_{2}$ & 1.54 & 1.62 & 1.49 & 1.47 & 1.14 & 1.17 \\
\hline $\mathrm{Fe}_{2} \mathrm{O}_{3}$ & 9.66 & 10.0 & 9.29 & 9.25 & 6.84 & 7.23 \\
\hline $\mathrm{MnO}$ & 0.04 & 0.04 & 0.04 & 0.04 & 0.03 & 0.03 \\
\hline $\mathrm{GaO}$ & 2.39 & 3.65 & 2.40 & 2.10 & 1.16 & 1.26 \\
\hline $\mathrm{MgO}$ & 1.25 & 1.65 & 1.26 & 1.15 & 0.93 & 0.95 \\
\hline $\mathrm{Na} 2 \mathrm{O}$ & 3.46 & 4.86 & 1.02 & 1.34 & 0.30 & 0.50 \\
\hline $\mathrm{K} 2 \mathrm{O}$ & 2.19 & 2.16 & 2.04 & 2.01 & 1.98 & 1.95 \\
\hline $\mathrm{BaO}$ & 0.32 & 0.29 & 0.37 & 0.38 & 0.24 & 0.26 \\
\hline $\mathrm{SrO}$ & 0.12 & 0.14 & 0.11 & 0.11 & 0.07 & 0.08 \\
\hline
\end{tabular}

